\title{
S5ynthesis
}

International Scientific Conference of IT and Business-Related Research

\section{NESIGURNOST ZAPOSLENJA, STRES I PRODUKTIVNOST ZAPOSLENIH}

\section{JOB INSECURITY, STRESS AND EMPLOYEE PRODUCTIVITY}

\author{
Saša Perić \\ Beogradska poslovna škola, Kraljice Marije 73, Beograd, Srbija
}

\begin{abstract}
Apstrakt:
Poslednjih nekoliko decenija u većini zemalja sveta primetna je pojava smanjenja prava radnika i sve veće nesigurnosti zaposlenja. Ova pojava uzrokovana je sa jedne strane promenom ekonomsko-političke paradigme na globalnom nivou, slabljenjem radničkog pokreta i deregulacijom radnog pravo na nivou država, a sa druge strane dinamičnim promenama u sferi tehnologije i potrebom za stvaranjem fleksibilnih i prilagodljivih modela poslovanja.

Dugoročno ili doživotno zaposlenje koje je ranije bilo uobičajeno u većini razvijenih zemalja, kao i u zemljama socijalističkog bloka, sada postaje privilegija sve manjeg broja ljudi. U situaciji u kojoj gotovo ničije radno mesto nije zagarantovano, mogućnost gubitka posla predstavalja potencijalni izvor stresa koji može imati negativne posledice, kako na zdravlje radnika, tako i na performanse organizacija. U ovom radu ispituju se različiti aspekti vezani za nesigurnost zaposlenja, kao i mogućnost određivanja korelacije između ove pojave, stresa i produktivnosti radnika.
\end{abstract}

\section{Ključne reči:}

nesigurnost zaposlenja, novi psihološki ugovor, stres na radnom mestu.

\section{UVOD}

U savremenom svetu sve je evidentnija dinamičnost poslovnog okruženja, koje je pod uticajem brojnih ekonomskih, političkih, društvenih i tehnoloških faktora podložno sve učestalijim promenama, koje je često teško predvideti. Konkurencija prelazi nacionalne granice i postaje globalna, kompanije se osnivaju, transformišu i gase u sve kraćem roku, a promene u tehnologiji zahtevaju veliki stepen adaptabilnosti i konstantno učenje, kako od strane pojedinaca tako i od strane organizacija. Ove fluktuacije dovode do promena u gotovo svim aspektima poslovanja, a to se naravno odražava i na položaj zaposlenih u kompanijama.

Ranije je jedna od osnovnih implicitnih pretpostavki svakog radnog okruženja bila da će zaposleni u zamenu za adekvatne performanse i posvećenost organizaciji dobiti relativno sigurno ili doživotno zaposlenje i predvidivu karijeru, ali su promene koje su se dogodile u poslednjih nekoliko decenija dovele do toga da je ovaj koncept postao prevaziđen. Neki autori ovo nazivaju kršenjem starog psihološkog ugovora i nasuprot njemu formulišu novi psihološki ugovor koji, takođe implicitno, podrazumeva da zaposleni od svog poslodavca može da očekuje adekvatnu nagradu za rad koji ulaže u periodu dok traje njihova međusobna povezanost i da pored toga, u najboljem slučaju, može da dobije priliku za učenje i razvoj, bez bilo kakvih obećanja za dugoročnu vezanost i stabilnost posla (Đorđević, 2012).

\section{Abstract:}

Over the last few decades, a global tendency towards the decline in labor rights and increase of job insecurity can be observed. This trend has been triggered on one hand by the change of the economic-political paradigm on a global level, and weakening of the labor movement and deregulation of labor laws on the national level, and on the other hand by dynamic changes in the field of technology and the need for creating flexible and adaptable business models.

Long-term or lifetime employment, which used to be common in most developed countries, as well as in the countries of the socialist bloc, is gradually becoming a privilege of a very small group of people. In a situation in which almost nobody's job is guaranteed, the possibility of losing a job becomes a potential source of stress, which can have adverse effects on both employee health and organizational performance. The paper examines different aspects related to the issue of job insecurity, and the possibility of determining the correlation between this phenomenon, stress and employee productivity.

\section{Key words:}

job insecurity, new psychological contract, stress in the workplace.

\section{FAKTORI NESIGURNOSTI ZAPOSLENJA}

Nesigurnost zaposlenja je globalni fenomen koji postaje posebno aktuelan u sledećim situacijama:

- U periodima recesije dolazi do potrebe za otpuštanjem velikog broja radnika, a poslednja velika kriza ovog tipa se dogodila 2007. godine, pri čemu su velike posledice pretrpele i najrazvijenije svetske ekonomije i zemlje u razvoju, a mnoge države se još uvek nisu potpuno oporavile od tog udara.

- U procesu tranzicije jedna od glavnih posledica privatizacije društvene imovine jeste veliko povećanje stope nezaposlenosti, što posebno postaje bitno kada se uzme u obzir činjenica da jedna trećina ukupne svetske populacije živi u zemljama koje se nalaze u procesu tranzicije.

- U privrednim granama koje su pod najvećim uticajem promena u tehnologiji i nauci, radni procesi su podložni čestim transformacijama, a radna mesta nisu stabilna, zato što vrlo brzo može doći do potrebe za smanjenjem radne snage ili za kadrovima sa potpuno drugačijim kvalifikacijama.

- Slabije razvijene ekonomije su podložnije uticaju globalnih političkih i ekonomskih promena, pa je stepen neizvesnosti u takvim privredama znatno veći, kako na makro tako i na mikro nivou. 
Kada uzmemo u obzir našu sredinu možemo primetiti čitav niz faktora koji utiču na nesigurnost zaposlenja: visoka stopa nezaposlenosti, povećana mobilnost radne snage, privatizacija i restruktuiranje radnih organizacija i težnja ka liberalizaciji pravne regulative koja bi trebalo da omogući sve lakše otpuštanje radnika od strane poslodavaca, bez obzira na radne učinke zaposlenog, godine staža, zdravstveno stanje i sl. Kao posledica svega ovoga u našoj zemlji je sve očiglednija pojava rada na crno, honorarnog zapošljavanja, prevremenog penzionisanja, vremenski ograničenih radnih ugovora, smanjivanja prosečnih i minimalnih nadnica, itd.

U ovakvoj situaciji postaje logično da će veliki broj zaposlenih svoje radno mesto posmatrati kao nesigurno. Najopštije gledano možemo razlikovati (Maslić Seršić \& Trkulja, 2009):

- subjektivnu nesigurnost posla, koja zavisi od karakteristika i percepcija idividue, $\mathrm{i}$

- objektivnu nesigurnost posla, koja je određena stvarnim faktorim iz radnog okruženja.

S obzirom na to da je Maslov u svojoj poznatoj hijerarhiji potreba, potrebu za sigurnošću stavio na drugo mesto, odmah iza fizioloških potreba, postaje jasno da je to jedan od temelja bez koga nije moguće ostvarenje potreba višeg reda: psiholoških potreba, potreba poštovanja i samoaktuelizacije (Maslow, 1970). Očigledna je činjenica da nesigurnost zaposlenja direktno uzrokuje stres, što je i dokazano u velikom broju radova koji su pokazali da nedostatak sigurnosti u sopstveno zaposlenje dovodi do pada psihološkog blagostanja radnika, nezadovoljstva poslom, anksioznosti, učestalijih psihosomatskih oboljenja, veće učestalosti bolesti srca i povišenog krvnog pritiska (De Witte, 1999; Modrek \& Cullen, 2013).

Nesigurnost posla se najopštije definiše kao neizvesnost u vezi budućnosti zaposlenja, a pri tom možemo razlikovati kvantitativnu i kvalitativnu nesigurnost. Kvantitativna nesigurnost se odnosi na brigu oko budućnosti zadržavanja sadašnjeg posla, dok se kvalitativna nesigurnost tiče percepcije mogućeg gubitka kvaliteta posla (Maslić Seršić \& Trkulja, 2009). Kvalitet posla se vezuje za: visinu plate, radne uslove, beneficije (kao što su bonusi, zdravstveno i penziono osiguranje), količinu posla koju treba obaviti, produžavanje radnog vremena, smanjenje broja slobodnih dana u godini i degradaciju, odnosno spuštanje na niži položaj u hijerarhijskoj lestvici. Ovi faktori možda nemaju podjednaku težinu kao mogućnost potpunog gubitka posla, ali takođe mogu imati veliki uticaj na stres i psihološko stanje radnika.

Neka istraživanja su pokazala da sama neizvesnost oko budućnosti zaposlenja može na duži period imati negativnije posledice nego samo gubljenje posla (Lazarus \& Folkman, 1984). Ovo bi se moglo objasniti činjenicom da čak i manja količina stresa deluje destabilizujuće ako je perzistentna u dužem vremenskom periodu, dok jači stres, kao što je onaj zbog gubitka posla, ima svoj definitivan ishod posle koga individua mora da se pomiri sa situacijom i da se orijentiše na traženje novog posla, odnosno da svoju energiju kanališe u kreativnom smeru. Postoji čitav niz postupaka koje mogu primeniti osobe koje su izgubile posao, kao što su: pisanje radne biografije, pretraživanje oglasa, slanje aplikacija, prijavljivanje na biro za zapošljavanje, sticanje novih veština ili prekvalifikacija, a pored toga u razvijenim zemljama koje imaju viši nivo socijalne zaštite građana postoji čitav niz mehanizama preko kojih država i kompanija u kojoj je pojedinac bio zaposlen pokušavaju da olakšaju ovaj period nezaposlenom, dajući mu šansu za doškolovavanje, socijalna primanja i psihološka savetovališta za suočavanje sa novonastalom situacijom. Sa druge strane, zaposleni koji samo imaju strah od gubljenja radnog mesta nemaju nikakve mehanizme zaštite i ne mogu očekivati od sistema bilo kakvu podršku, jer bez obzira na to koliko je problem za njih velik i značajan, on predstavlja samo neprecizan strah od nečega što se još uvek nije desilo.

Mnoga istraživanja su se bavila pitanjem koliko je osećaj nesigurnosti zaposlenja povezan sa pojedinim psihološkim ili demografskim karakteristikama radnika. Rezultati ovih istraživanja su uglavnom vrlo nekonzistentni, ali među zaključcima koji bi se mogli izdvojiti je i taj da su stresu od nesigurnog zaposlenja podložniji stariji radnici (od 45 do 54 godine), nego mlađi (od 35 do 44 godine) (Rodríguez Feijóo, 2004). Ovo se može objasniti činjenicom da stariji radnici imaju više teškoća u pronalaženju novog posla i u adaptiranju na nove tehnologije i nova radna okruženja. Takođe, pokazalo se da radnici iz više srednje klase doživljavaju manje stresa vezanog za nesigurnost zaposlenja od onih iz niže srednje klase. Nije potrebno previše objašnjavati ovu činjenicu zato što je očigledno da pripadnici viših društvenih slojeva imaju veći stepen finansijske nezavisnosti, bankovne račune, nekretnine i druge izvore sredstava zbog čega gubitak posla verovatno neće dovesti do direktnog ugrožavanja njihove osnovne egzistencije, kao što je to slučaj kod radnika iz nižih slojeva. Sa druge strane, ovo može izgledati potpuno drugačije u zavisnosti od toga u kojoj se zemlji sprovodi istraživanje. U državama u kojima postoji visok stepen kreditne zaduženosti građana to se odražava kroz činjenicu da i ljudi iz viših srednjih slojeva često poseduju veliki broj kredita, pa tako gubitak posla može da dovede do gubitka hipoteke nad kućom, automobila i drugih vezanih imovina, čak i kod porodica sa znatno višim životnim standardom.

Istraživanje sprovedeno u nekoliko američkih kompanija posle recesije, u periodu između 2008. i 2012. godine pokazalo je da je stepen stresa znatno viši u onim fabrikama u kojima je došlo do većeg broja otpuštanja, nego u fabrikama u kojima je postojao manji procenat otpuštanja. Ovo pokazuje da smanjivanje broja zaposlenih u nekoj kompaniji ili postrojenju dovodi do direktnog povećanja nesigurnosti zaposlenja i stresa kod radnika koji su „preživeli” otpuštanja (Modrek \& Cullen, 2013). Takođe je pokazano da je zabeležen viši nivo stresa kod stalno zaposlenih nego kod honoraraca, što je uzrokovano činjenicom da radnici koji su zaposleni na određeno vreme i dobijaju nadnice na osnovu broja radnih sati u toku dana ili nedelje imaju mnogo manje toga da izgube, jer je njihov status definisan kao privremen, a kompenzacija zagarantovana određenim sindikalnim standardima. Sa druge strane, trajno zaposleni su pored mogućnosti gubitka posla bili suočeni sa potencijalnim povećanjem radnih obaveza, da bi se na taj način pokrilo novonastalo smanjenje radne snage, pri čemu ovo dodatno radno opterećenje ne bi moralo biti plaćeno, već bi se nasuprot moglo pojaviti smanjenje plata za sve zaposlene.

Još jedna dimenzija koja se pokazala kao značajna, makar u društvima sa izraženijom patrijarhalnom i tradicionalnom crtom, jeste da su stresu izazvanom nesigurnošću zaposlenja podložniji muškarci nego žene. U ovakvim društvima muškarci se posmatraju kao glave porodice i od njih se očekuje da se brinu o ostalim članovima, te je tako pritisak na muškarce znatno izraženiji, posebno ako je njihovo zaposlenje jedini izvor prihoda za čitavu porodicu (Maslić Seršić \& Trkulja, 2009; De Witte, 1999).

S obzirom na vrlo neujednačene rezultate istraživanja koja nastoje da pokažu korelaciju između stresa izazvanog nesigurnošću zaposlenja i određenih demografskih, psiholoških i kulturoloških faktora, teško je izvući bilo kakve definitivne zaključke, ali okvirno bi se moglo odrediti da među najugroženije grupe spadaju:

- radnici u kompanijama u kojima je već došlo do značajnijeg smanjenja radne snage,

- radnici koji pripadaju socijalno ugroženom delu stanovnišstva, 
- imigranti i etničke manjine,

- sezonski i honorarni radnici,

- stariji zaposleni,

- radnici čije profesije postaju tehnološki zastarele,

- novozaposleni,

- radnici na probnom radu.

\section{POSLEDICE NESIGURNOSTI ZAPOSLENJA}

Stres izazvan osećanjem nesigurnosti posla ostavlja posledice na zaposlene i na organizacije u kojima rade. Negativne posledice stresa na psihofizičko zdravlje čoveka odavno su poznate i dokazivane i predstavljaju predmet istraživanja medicinskih nauka, a potrebno je detaljnije se pozabaviti organizacionim posledicama koje ovakav stres uzrokuje. Nesigurnost posla ima odlučujuće posledice na stavove zaposlenih prema radnim zadacima i prema organizaciji, kao i na ukupne odnose i ponašanja u organizaciji (Sverke et al., 2012).

Poslodavci često pokušavaju da iskoriste loše stanje u privredi i na tržištu rada, angažujući honorarne radnike ili radnike na određeno vreme. Na taj način oni pokušavaju da smanje sopstvene rizike uz povećanje zalaganja zaposlenih. Takođe, kompanije koje su bile prinuđene da smanje broj zaposlenih, često povećavaju opterećenje preostalih zaposlenih novim radnim zadacima, pretpostavljajući da to neće naići na otpor, jer su u uslovima nesigurne ekonomske klime radnici orijentisani na zadržavanje radnog mesta, čak i po cenu značajnog pogoršanja radnih uslova. Radnici koji ostanu u kompaniji posle downsizing-a često pokušavaju što više da se istaknu svojim radom, kako bi osigurali sebi mesto posle eventualnih novih otpuštanja. Zaposleni tada pokazuju preteranu odanost kompaniji i njenim ciljevima, rade prekovremeno bez dodatne plate, dolaze na posao čak i kada su bolesni i prezimaju na sebe veliki broj zadataka kako bi ostavili što bolji utisak kod nadređenih menadžera.

Ovakva ponašanja mogu na prvi pogled delovati kao nešto što će imati pozitivan efekat za kompaniju, ali činjenica je da pozitivni ishodi mogu biti samo kratkog karaktera, dok će na duge staze stres proizvesti negativan efekat na obe strane. Preterano angažovanje zaposlenih će dovesti do kratkotrajnog povećanja efikasnosti poslovanja, ali će tokom vremena rezultovati preteranim sagorevanjem (Maslić Seršić \& Trkulja, 2009). Kompanija u kojoj zaposleni sagorevaju u toku obavljanja svog posla biće prinuđena da izdvaja veća sredstva za troškove zdravstvenog osiguranja, povećaće se apsentizam radnika, doći će do fluktuacije radne snage, što će sa druge strane iziskivati dodatne troškove za regrutaciju, selekciju i obučavanje novih radnika, a produktivnost će opadati jer je uvek potrebno određeno vreme za potpuno uklapanje novih radnika u sredinu i u već razrađene radne strukture i procese.

Neki autori ističu da postoji određeni optimalni nivo sigurnosti zaposlenja, pri kome će postojati maksimalna produktivnost za organizaciju (Brockner, 1992). Pretpostavka je da kada posao nije doživotno zagarantovan, već zavisi od pokazanih rezultata na radu, zaposleni će pokušavati da daju svoj maksimum i zadrže svoju poziciju preko dobrih radnih učinaka, ali kada ovaj pritisak postane veći i posao deluje sve nesigurnije dolazi do opadanja produktivnosti, jer zaposleni usled velikog stresa nisu u stanju da ostvare maksimum svojih potencijala $i$ $\mathrm{u}$ jednom trenutku prestaju da se identifikuju sa kompanijom i njenim rezultatima. Ovaj efekat se naziva i organizaciono povlačenje (Dekker \& Schaufeli, 1995).

Organizaciono povlačenje za posledicu ima kratkoročnu orijentisanost, nezdravu konkurenciju među zaposlenima, zadržavanje određenih informacija, rivalitet među različitim sektorima i otpor prema promenama, jer se iste doživljavaju kao nešto što može ugroziti sopstvenu poziciju u organizaciji. Ovi efekti mogu imati još značajnije posledice na višim nivoima hijerarhije jer menadžeri počinju da izbegavaju rizik, da donose samo „sigurne” odluke, što dugoročno može imati izuzetno negativne posledice, zato što nekada upravo preuzimanje rizika ili značajnije restruktuiranje poslovanja predstavljaju neophodnost za opstanak i konkurentnost kompanije u budućnosti (Đorđević, 2012).

Kao preporuka se najčešće navodi da kompanije moraju biti iskrene prema svojim zaposlenima, da ne smeju prikrivati potencijalna smanjenja radne snage koja se mogu desiti u budućnosti i da kroz inovativne strategije upravljanja ljudskim resursima treba da podstiču stalno obrazovanje zaposlenih, fleksibilnost radnih zadataka i organizacionih struktura, multifunkcionalnosti i dinamičnost radne snage. Na ovaj način se organizacija osposobljava za lakše adaptiranje na promene koje mogu nastati u budućnosti, a zaposleni dobijaju šira i fleksibilnija znanja koja će ih čak i u slučaju gubitka posla učiniti „Zapošljivijim” i bolje pripremljenim za snalaženje na tržištu radne snage (Maslić Seršić \& Trkulja, 2009; Brockner, 1992).

Nesigurnost zaposlenja je činjenica izazvana trenutnom ekonomsko-političkom situacijom u svetu, a efekti nesigurnosti se pre svega tiču stresa kod zaposlenih, dugoročnih negativnih posledica po zdravlje koje ovakav stres izaziva, ali i negativnih posledica po organizacije. Po nekim istraživanjima procenjuje se da samo u SAD-u privreda tripi godišnje gubitke od preko 300 milijardi dolara usled apsentizma, smanjene produktivnosti, medicinskih, pravnih i osiguravajućih troškova izazvanih stresom na poslu. Statistika Američke psihološke asocijacije pokazuje da je 51\% zaposlenih izjavilo da su u 2009-oj godini bili manje produktivni usled stresa, a $48 \%$ amerikanaca je nameravalo da potraži novi posao nakon stabilizacije privrede, usled razočaranosti u ponašanje svoje kompanije tokom ekonomske krize (American Psychological Association, 2010).

\section{ZAKLJUČAK}

Nesigurnost zaposlenja je fenomen koji postaje sve prisutniji u savremenom poslovnom okruženju i koji sa sobom nosi niz posledica, koje utiču kako na funkcionisanje organizacija, tako i na psihičko stanje zaposlenih. Slabljenje zakonskih regulativa koje štite prava zaposlenih i sve prisutnija tendencija stvaranja fleksibilnih radnih organizacija čine ovu problematiku veoma aktuelnom, tako da se u budućnosti mogu očekekivati obuhvatnija i detaljnija istraživanja ovih problema. Ta istraživanja moraće da uzmu u obzir performativnost organizacija, psihološko stanje radnika i uslove koji postoje u širem društveno-ekonomskom okruženju, da bi se pronašli odgovarajući modeli funkcionisanja koji će obezbediti dugoročnu održivost. Sve ovo ukazuje na potrebu za stvaranjem zdravijih radnih sredina, u kojim će se zaposleni osećati sigurno, gde će njihove kompetencije biti adekvatno vrednovane i gde će im biti pružena mogućnost za dodatno učenje i usavršavanje. Jedino tako se može napraviti stabilno okruženje u kom će radnici biti motivisani da rade za ciljeve organizacije, što će na dugoročnom planu pozitivno uticati na poslovanje kompanija i dobrobit zaposlenih.

\section{LITERATURA}

American Psychological Association. (2010). Psychologically Healthy Workplace Program - Fact Sheet: By the Numbers. Preuzeto 14.02.2015 sa http://www.apaexcellence.org/assets/general/2010phwp_fact_sheet.pdf 
Brockner, J. (1992). Managing the effects of layoffs on survivors. California Management Review, 34(2), 9-28.

De Witte, H. (1999). Job Insecurity and Psychological Well-being: Review of the Literature and Exploration of Some Unresolved Issues. European Journal of Work and Organizational Psychology, 8(2), 155-177. DOI: 10.1080/135943299398302

Dekker, S.W.A., \& Schaufel,W. B. (1995). The Effects of Job Insecurity on Psychological Health and Withdrawal: A Longitudinal Study. Australian Psychologist, 30 (1), 57-63.

Đorđević, B. (2012). Nesigurnost zaposlenja - Priroda, posledice i strategije upravljanja. Themes Journal for Social Research, 01/2012, 335-350.

Lazarus, R.S., \& Folkman, S. (1984). Stress, Appraisal and Coping. New York: Springer Publishing Company, Inc.

Maslić Seršić, D., \& Trkulja, J. (2009). Nesigurnost posla kao predmet istraživanja u psihologiji: teorije, operacionalizacije, nalazi. Social Research Journal for General Social Issues, 3/2009, 523-545.
Maslow, A.H. (1970). Motivation and personality. New York: Harper \& Row.

Modrek, R., \& Cullen, M.R. (2013). Job insecurity during recessions: effects on survivors' work stress. BMC Public Health, 13: 929. DOI: $10.1186 / 1471-2458-13-929$

Rodríguez Feijóo, N. (2004). Job insecurity and stress level. Interdisciplinaria, 99, 249-257.Preuzeto 21.02.2015. Sa http:// www.scielo.org.ar/pdf/interd/nesp/nespa18.pdf

Sverke, M., Hellgren, J., Näswall, K. (2012). No security: A metaanalysis and review of job insecurity and its consequences. Journal of Occupational Health Psychology, 7(3), 242-264. 